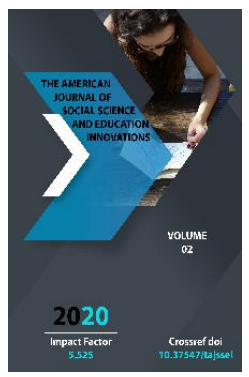

\title{
Islamic Teaching On Economic Relations And Trade
}

\author{
Bazarova Gulnora Gulamovna \\ Associate Professor of Humanities Department, Andijan Machine-Building Institute, \\ Uzbekistan
}

Journal Website:

http://usajournalshub.c

om/index,php/tajssei

Copyright: Original

content from this work

may be used under the

terms of the creative

commons attributes

4.0 licence.

\section{ABSTRACT}

The article deals with the attitude of the religion of Islam to economic problems. In particular, in the current time of economic reforms, this is of great importance in our country, where the majority of the population is Muslim.

In the teachings of Islam, its different streams have different attitudes towards the category of private labor. The article also discusses the importance of trade. As a help to people, great importance is attached to work in the formation of socio-economic relations, where Islamic values play an important role.

\section{KEYWORDS}

Islam, economic relations, entrepreneurship, labor, trade, Islamic ethics.

\section{INTRODUCTION}

In the formation of market relations, knowledge of the teachings of the Islamic religion on these issues is of great importance, since the majority of the population in our country are Muslims. In Islam, a special place is occupied by work that benefits others, where the main attribute is honesty.
Significant geopolitical changes and globalization processes taking place in the modern world in recent decades force us to take a fresh look at the role of Islam in it. Islam is becoming an increasingly important factor in world politics. Back in the late 70 s - early 80 s of the XX century, the so-called "Islamic 
boom" contributed to the politicization of Islam and the Islamization of politics in Muslim countries. One of the main reasons for this phenomenon is that Islam, as an integral religious system, claims to comprehensively regulate all aspects of the life of Muslims. This is facilitated by the historically formed and entrenched in the public consciousness ideas about the inseparability in Islam of religion and politics, spiritual and secular, Islam and the way of life of Muslims in general.

A significant number of historical, oriental, philosophical and political science studies are devoted to the study of Islam in Central Asia, since the socio-cultural phenomenon of Islam is so multifaceted that it requires an interdisciplinary approach. First of all, it is necessary to note the general theoretical historical and philosophical works devoted to the problems of the emergence and spread of Islam in the Central Asian region. These are the works of famous Russian and Soviet researchers such as G.E. Grünbaum, V.V.Bartold, S.M. Abramzon, JI Vasiliev. S., Ermakov I.B., Polonskaya Jl. R., Stepanyants M. T., Valikhanov Ch., Abdyldaev M., Amanaliev B., Shukurov III., Muminov A. and others, who played an important methodological role in understanding the role and place of Islam in Central Asia.

Recently, much attention has been paid to the theory and practice of management based on the principles of Islam in the domestic scientific literature. A wide range of issues on this issue are considered in the works of R.I.Bekkin, N.V. Zhdanov, A. Zhuravlev, N.A.Ivanov, N.M. Mamedova, L.R.Syukiyainen and others. Particular interest in scientific circles cause the principles of functioning and the specificity of the activities of Islamic financial institutions. Among the authors, in whose works this topic is considered in detail, one should name A.S.Boldzhurova, V.A.Isaev, A.O. Filonik, A.V. Fedorchenko, M.Kamenskikh, E.N. Miroshnik, M.Miftyakhetdinova , A. A. Maksimova, T. P. Miloslavskaya, V. V. Pavlova, Yu. Prudnikova, P. Trunin and others. Development of the institution of entrepreneurship in the Islamic world, including among the Muslims of the Russian Empire, are analyzed in the works of M.Z. .Gibadullin, Al Ionova and others. The economic development of Muslim countries and their role in the modern system of international relations has become a subject of study in the works of A. Arabazhdan, SB Dmitriev, V. Melyantsev, N. Yu. Ulchenko.

At the present stage, when studying Islam, works that draw attention to its economic foundations, for example, in the article by N.S. Akhtyamova "Islamic economic model: conceptual and theoretical foundations" examines the main features of the Islamic model of the economy, their impact on the economic, legal and economic activities of subjects of Islamic business. The author analyzes the legitimacy of using the concept of "Islamic economy", substantiates the correctness of this concept in the interpretation of the "Islamic economic model" and examines the practical aspects of the application of Islamic laws (Sharia) in economic activity.

\section{MAIN PART.}

Much attention is paid to economic, financial and banking relations in Islam in the speeches of the Secretary General of the World Union As you know, in all religious teachings, great attention is paid to the problems of economics, economic relations and entrepreneurship. The teachings of Islam also describe in detail economic relations and the requirements for them. Such provisions are 
reflected in the Quran, hadiths and instructions of the Prophet Mohammed. They are important because they contribute to building a just society in which honest people can live and work with dignity.

The Islamic economy is aimed at ensuring the basic needs of a person using harmonious means, while the traditional economy is based on the material principle, to some extent disregarding moral laws and prohibitions. The Islamic economy is based on the recognition of private property, as interpreted by the Sharia. Equally, it seeks to spread the concept of social solidarity by providing conditions for unity and cooperation between capital and labor, while completely denying monopoly, as well as achieving social justice through reasonable wages and the eradication of unemployment. On this basis, the Islamic economy succeeds in solving the most difficult problems of our time, in establishing a balance between the needs of the individual and the progress of society.

When an economic reform is carried out, market relations are formed, which means new economic relations in society, knowledge of the teachings of Islam on these issues is of great importance. This is all the more important for our country, the majority of whose population is Muslim.

Islam condemns inaction, calls for activity in one's life, both materially and religiously. Moreover, he should not be engaged only in religious affairs, while launching practical, everyday affairs. This is not pleasing to Allah. A person should deal with the direct affairs of his life in the name of Allah, not forgetting him, and vice versa, he should not dive only into earthly affairs, while forgetting about God. Islam praises work and hard work. Honest work is considered one of the good qualities of a Muslim. Bukhari quoted the words of the Prophet Mohammed that honest work should be considered as a jihad performed in honor of the great Allah: "If this person works in order to support his small children, elderly parents, or even just to satisfy his own needs, then in such In this case, all his work should be considered as a jihad, performed for the glory of Allah.

Islam teaches that a person should live by his honest labor and benefit others. Work that benefits others is decent work. But if a Muslim earns his living in an unworthy way to the detriment of others, then this is forbidden work, that is, haram. For this religion there are no inferior and shameful professions. Only honesty is required. Allah loves honest workers. Their work is worthy, that is, halal. The Qur'an and hadiths often speak of legal labor, the good of labor and the importance of constantly being something useful: "Let him not enter Paradise, who earns his living in an illegal way" (Ahmad, Bayhaki) [4].

Islamic ethics teaches that a true Muslim should provide care and assistance to the elderly and children. This is what the hadith from Termizi says: "He who does not have compassion for small children and does not respect the old is not a man." Also, the Islamic religion teaches Muslims to take care of their parents: "Let the one who did not help his parents be ashamed, for he has lost his right to enter Paradise" (Termizi).

It is known that trade has long been developed in Central Asia. Those who are engaged in trade today are religious people. Among them there are many true Muslims who really observe Islamic precepts, but at the same time there are many who, by deceit and in various ways, contribute to unjustified price increases. Our observations show that 
among a certain part of Muslim traders such a requirement of Islam as "iman", on which Islamic morality is based, is not always respected.

Further, Islam punishes greed. An unbeliever, but a magnanimous person is dearer to God than a curmudgeon believer "(Termizi) and praises magnanimity:" The pious ... those who ... out of love for him feed the poor, the orphan, the captive (saying): "We feed For the sake of God, we do not demand from you either payment or gratitude. " that if a Muslim gives alms (saadaka) once, then he will receive a reward from Allah 700 times.

Today there are many businessmen, entrepreneurs who help orphanages, homes for the elderly and disabled and other needy people in every possible way. Their actions should serve as an example for others. At the same time, Islam requires an able-bodied person to do a useful job and bring benefit to himself and people. A Muslim can only ask for alms only in desperate situations and in case of severe need: "Only three categories of people are allowed to ask for alms: those who are in hopeless poverty, those who have lost their breadwinners and cannot feed themselves, and those who owe a lot and cannot pay him "(Abu Daud).

The acquisition of goods and services is relevant for any society, whatever the technological development. In this sense, the need to regulate trade in order to meet the interests of both sellers and buyers becomes essential. In Islam, these points were taken into account at the dawn of the formation of religion: the Koran and the Noble Sunnah contain many economic principles and rules, the observance of which will help to avoid problems in this world and in eternity.
Therefore, Islam specifically sanctifies trade. It occupies a special place in the Muslim civilization. Trade is a godly business. But it is trade, not speculation. There is no concept of speculation in Islam. But the merchant is required to be honest and comply with other Islamic precepts. The following hadith from Termizi is cited: "An honest and incorruptible merchant - among the prophets, righteous and martyrs."

Trade in Islam is considered on the basis of Sharia what is trade from the point of view of Sharia? She has her own requirements, conditions. Trade also has its own definition, the basics in Sharia, the conditions for those who are engaged in trade, the terms of the contract, the conditions for the goods sold. If we briefly dwell on them, then trade is "the exchange of something" or which means "the exchange of one valuable thing for another valuable thing with the satisfaction of both parties." So, we see that the first condition regarding the trade itself is that the thing being sold must be of value. The trade relationship consists of two parties - offer and consent, and there must be mutual agreement between them.

In addition to these two essential elements of trading, there are also terms of purchase and sale. They are also mandatory:

1. The seller and the buyer must be of sound mind.

2. The wording of the proposal and agreement must be clear if trade is impossible without a negotiation process.

3. The offer and consent must refer to the same basis of the subject of the transaction. That is, if the proposal referred to five seedlings, then consent cannot be given about seven seedlings. 
4. The transaction must take place without a large semantic gap between the offer and the consent. Suppose, after a potential buyer turned to a person who owns some interesting object or resource, the latter simply left without giving any intelligible answer to the offer made, but agreed after some time, when the buyer, perhaps, forgot about the fact of his proposal. In this situation, the fact of purchase and sale did not occur. It's another matter if a potential seller told the buyer that he needs some time to think about the deal. In this case, the relationship between the two entities is of a completely different nature, they already have some kind of agreement that must be fulfilled (meaning, first of all, information notification of consent or refusal to conduct a transaction after thinking about it).

5. The product must be of value (that is, one grain of rice cannot act as an object of the transaction, since its value is extremely low, it cannot satisfy hunger, etc.) and be halal (for example, you cannot sell alcohol).

6. The goods must be owned by the seller. In addition, you cannot sell objects that are in the use of all people (for example, rivers, lakes, mountains, hills, seas, and so on).

7. You cannot sell something that is not yet available and that depends on some natural factors (for example, the fruits of a plant). This prohibition does not apply to manufactured goods.

8. Purchase and sale is carried out in relation to an object, the properties of which are known. For example, an unknown sheep in a herd, which may have some physical defects, cannot be sold.

When a commodity exchange has taken place between the parties, it can also be canceled after the corresponding offer has been received. If in this case the goods were destroyed, then you can return the money for it or give something equivalent.

In Islam, there are also some prohibitions on activities in the trade that harm other people. They are divided into those that cause general harm, and those that harm only those people with whom the person deals directly. Let us list some of these actions, for in our relationships with people we need to avoid injustice and adhere to sincerity.

\section{Weighing, measuring}

Today one of the most common vice among merchants is weighing, measuring. For example, at gas stations they do not add fuel, that is, by subtracting others, they add to themselves. This is the gravest $\sin$ and violence, which are prohibited by the Qur'an and hadith. On this occasion, Allah Almighty in His Holy Quran says: "Great grief and the abyss of Hell for those who weigh, who take in full when they measure and weigh for themselves, and when measured and weighed to people, they decrease in weight. Don't they think that after death they will be resurrected again for interrogation on the great Day of Judgment ?! (Surah "Al-Mutaffifinah", ayahs 1$6)$.

The great day, which the Qur'an narrates, is the day when people will be in unbearable cramped conditions, experiencing intense hunger, thirst and fear, when the sun is approaching, and people will drown in their own sweat. This is the day when people, unable to endure the torment, will shout to be sent as soon as possible at least to Hell.

It is necessary to weigh and measure for others as you would like others to do it for you. And this can be achieved by properly 
adjusting the scales and adding a little when you sell and decreasing when you buy, since it is impossible to achieve absolute accuracy.

\section{Trade in stolen goods}

It should also be noted that in Islam it is strictly forbidden to engage in the purchase and sale of stolen goods. If a person knows that a given product is stolen, taken by force or obtained by deception and unauthorized ways, it cannot be bought and sold. All participants in such trade relations fall into sin and are responsible for their actions. We must not forget that we are responsible for our every act, for every step and for every moment.

There is no need to ask the seller where and how the goods were purchased, but if they ask for a suspiciously low price for the goods, then the buyer must find out the reason for this, so as not to fall into sin, because this is usually how they sell stolen goods. If it turns out that this product has been stolen, then you can neither sell nor buy it. Small wealth earned by weighing and deceiving buyers will never pay off the huge troubles that Allah sends to a person in this and in the other world as punishment. During the time of the Prophet Shu'aiba (peace be upon him), Allah Almighty destroyed an entire people, among whom it was customary to weigh and deceive people when trading. One stranger's penny can cost billions of rubles in the next world. In the hadith of the Prophet (peace and blessings of Allah be upon him) it is said: "It is forbidden to underweight the goods even for a small fraction." Merchants who give weight to people deceive thousands of people, which is a particularly grave sin. Even if such merchants, regretting what they had done, want to ask the buyers for forgiveness, it will be impossible, since it is difficult to find them!
It is also necessary to pay special attention to this.

\section{Hiding product defects}

Another common deception in trade today is the concealment of product defects: shoes, clothes, fruits, vegetables are put up with the best side up, and the spoiled side of the product, its shortcomings, are hidden. They sell gasoline, mixing it with ethyl, diesel fuel, sell counterfeit banknotes, etc. The prohibition of such deception is indicated by a hadith, which says that once the Messenger of Allah (peace and blessings of Allah be upon him) reached out his hand for bread, intending to buy it. The bread was soggy underneath. Then the Prophet (peace and blessings of Allaah be upon him) asked the seller about this, and he replied that the bread got wet because of the rain. The Prophet (peace and blessings of Allaah be upon him) asked: "Why then don't you put the bread soaked side up?" Then he said: "He who deceives us is not one of us" (Imam Muslim).

The hadith says: "If a person sells something, hiding his flaws, flaws, then he will be under the wrath of Allah Almighty, and the angels will constantly curse him" (Imam Ibn Majah). In addition, the following message testifies to the obligatory display of sincerity, which should find its expression in pointing out the defects of the goods. When the Prophet (peace and blessings of Allaah be upon him) took an oath of allegiance to Islam from Jareer (may Allaah be pleased with him) and he was about to leave, the Prophet (peace and blessings of Allaah be upon him) pulled his clothes and set a condition regarding the manifestation of sincerity towards every Muslim. After that, Jarir (may Allah be pleased with him) always pointed out to the buyer the shortcomings of the goods sold, and then asked him to decide: "If you want, take it, and 
if you want, leave it." When they said to him: "If you continue to do this, then your trade will not work!", - he replied: "Indeed, we have sworn to the Messenger of Allah (peace and blessings of Allah be upon him) that we will be sincere towards everyone to a Muslim! "

Therefore, if the product has any flaws, it must be told honestly. A person can do this if he realizes that the sale of a product, the shortcomings of which he will hide, will not increase, but will reduce his lot and deprive him of his benefits, for Allah can destroy what he has collected by deceit in the blink of an eye. Therefore, a reasonable person will prefer only honestly earned.

\section{Over-praising a product}

It is not (haram) to praise a product by attributing qualities that are not inherent in it, since this is a lie, deception and injustice, and the one who lied will someday be disgraced. Especially unacceptable is the false oath, which some people often resort to in our time. The hadith says: "A false oath promotes the sale of goods, but also deprives it of grace (barakat)" (Imams Al-Bukhari, Muslim). However, it is possible to describe the merits of a product that it possesses without exaggeration.

\section{Speculation}

It is prohibited to engage in speculation (ichtikar). Speculation means the special postponement of products that people are in dire need of until prices rise in order to sell at a higher price, or buying goods in bulk at a lower price and storing them until the price rises for the purpose of later resale. This is a manifestation of injustice towards everyone, and a person who does this is blameworthy from the point of view of Sharia. This applies to those cases when a product or food is in short supply, and people need it, and the delay in selling them may cause some harm. An indication of the prohibition of buying for the purpose of speculation are the words of the Messenger of Allah (peace and blessings of Allah be upon him): "No one will buy anything except a sinner" (Imam Muslim). In another hadith narrated by Ibn Asakir, it is said: "If someone puts aside foodstuffs until the price increases for forty days, and then distributes it all as charity, charity will still not atone for the sin that this person committed." Sending your women on shopping trips

Recently, such an unworthy and shameful custom has spread, such as sending women to trade in other cities and even countries. A woman is forbidden to travel without an accompanying mahram (father, husband, son, brother, etc.). If women do not agree to stay at home, then why don't men go along with their wives, daughters, sisters, mothers to accompany them ?! Why do they stay at home sending their women to places like this ?! Or why are they not ordered to stay at home, content with the worldly wealth that they have ?!

It is written in theological books that a person who is not busy with work and is a dependent, having no valid reasons from the point of view of Sharia, is no different from a pregnant weak woman who must be provided with all that is needed, that he has no share in the man's business. , according to the words of the Almighty: "Husbands rule over wives, since Allah gave one advantage over others, and because they support others at the expense of their property" (surah "An-Nisa '", ayah 34).

\section{Hiding the cost of an item}

The merchant is also not allowed to hide the value of the goods he is selling. Therefore, if you are asked for a price, you should always 
tell the truth about the current prices. It is known that the Messenger of Allah (peace and blessings of Allah be upon him) forbade meeting caravans, because merchants could buy all goods from them and artificially raise the price. The Prophet (peace and blessings of Allaah be upon him) said: "Do not meet caravans ..." (Imams Al-Bukhari, Muslim). In addition, the Messenger of Allah (peace and blessings of Allah be upon him) forbade a settled resident to sell for a Bedouin. This refers to the following case: when a Bedouin brings food to the city, wanting to sell it as soon as possible, and a city dweller says to him: "Leave them to me, and I will wait for the prices to rise and set a high price." This vice is also very common in our society today. For example, in the market conditions and prices are dictated by one person or a group of persons, and there are even cases when some sellers are not allowed to make discounts through threats. But the monopoly on prices is prohibited.

All these prohibitions indicate that it is unacceptable to hide information about the prices prevailing for the goods either from the seller or from the buyer, as it is unacceptable to hide what, knowing about what, a person would not conclude an agreement. Such actions are a form of deception, which is strictly prohibited in Islam. It is unacceptable, taking advantage of the inattention and ignorance of the owner of any product, to conceal from him the fact that his product has risen in price or the price of the product has dropped; if a person does so, it will mean that he is committing a sin and does not adhere to justice and sincerity.

The most basic trading rules are highlighted above.
Islam prohibits usurious activities and condemns those who support them. Based on this, it should be noted that in all this, the personal benefit of a Muslim should come second. To help people. For honest labor of a Muslim.

\section{CONCLUSION.}

Currently, Islamic values are the most important element of the spiritual life of the Uzbek people. The ideology of independence developed by the President of our republic Sh.M. Mirziyayev penetrates into all spheres of life, acquires more and more specific content, and is approved as a guide to practical life. From a theoretical concept, it turns into a practical embodiment of the real process of development of society. Therefore, the formation of a new personality is a process of forming an active life position. Activity in the social sense can be formed in material life itself and then gradually rise, rise to the norm, the principle of morality. Therefore, the formation of a moral image is a process of forming an appropriate system of necessary socio-economic relations. In this whole process, an important role belongs to Islamic values, which can play an important role in the economic consciousness of people and can contribute to the formation of economic relations necessary for society in a market economy.

Islamic ideology, deployed in the spirit of creation, as a unifying factor, can play a huge role in solving the problems facing society.

\section{REFERENCES}

1. Quran. Translation and comments by I.Yu. Krachkovsky M., 1963.

2. Maksud R. Islam. -M .: Fair-press. 2001.-S. 201. Maksud R. Islam. -M .: Fair-press. 2001. 
3. Ulrich Rudolph. Al-Moturidiy wa Samarkand sunniylik ilohiyoti. T., 2001.

4. Maksud R. Islam.-M .: Fair-press 2001.-P.201

5. Evdokimov VV, Gritsishen DA Islamic economic doctrine as an environment for the formation and development of the Islamic accounting model // International accounting. 2012. № 29. [Electronic resource] // URL: http: // www. Fi nizdat.ru/journal/interbuh/detail.php? ID = 52161 (Date of treatment 09.24.2016).

6. Akhtyamov Niyaz Saubanovich. Islamic economic model: conceptual and theoretical foundations Vestnik RSUH. Series "Economy. Control. Law "2013

7. Ignatova T., Dobaev A. Islamic economy and the evolution of the hawala system Islam in the modern world. 2016. Volume 12.No. 4.

8. Speech by the Secretary General of the World Union of Muslim Scientists Ali Muhiddin al-Karadagi at the $\mathrm{X}$ International Muslim Forum. December 10, 2014, Moscow.

9. Gibadullin M.Z., Vakhitova T.M. Fundamentals of Islamic Economics: Theory and Practice of Management. Textbook / - Kazan: TGGPU, 2009 -- 195 p. 